18. Kalinovsky A.O. Trends and strategies of aviation industry development in Ukraine / A.O. Kalinovsky, N.I. Gorbal, N.L. Kalinovskaya // Business-inform. 2016. No. 8. P. 88-94.

19. Five Steps to Rescue the National Aircraft. Electronic resource. Access mode: https://defenceua.com/index.php/statti/publikatsiji-partneriv/4559-pyat-krokiv-z-poryatunku-vitchyznyanoho-litakobuduvannya

20. Chronicle of the dive industry, or How Ukraine loses its aircraft. Electronic resource. Access mode: https://www.epravda.com.ua/publications/2018/08/21/639792/.

Отримано 10.02.2019

\title{
УДК: 658.8:005.52:631.11
}

\section{ЗБУТОВА ТА ЦІНОВА ДІЯЛЬНІСТЬ В УПРАВЛІННІ КОНКУРЕНТОСПРОМОЖНІСТЮ ПІДПРИЕМСТВА}

\author{
Юлія Калюжна; Тетяна Боровик; Вікторія Даниленко
}

\author{
Полтавська державна аграрна академія, Полтава, Україна
}

\begin{abstract}
Резюме. У сучасних умовах на ефективність функціонування підприємства впливає комплекс політичних, економічних та соціальних чинників. Для конкурентоспроможності підприємства є досить важливим етапом установлення ціни, адже метою його функціонування є отримання максимального прибутку. Крім того, підприємству необхідно не лише виробити, а й збути свою продукцію з умовою отримання прибутку, а це стає можливим лише за правильного вибору цінової та збутової політики.

При проведенні дослідження виявлено, ще в управлінні конкурентоспроможністю підприємства важливу роль відіграють елементи маркетингу, а саме збутова та цүінова політика. Вони займають одну з ключових позицій у діяльності підприсмства, адже вони є заключним етапом його функціонування, а точніше реалізації споживачам кінцевого продукту. Отже, досліджено, щзо в управлінні конкурентоспроможністю підприємства є взаємозв'язок між збутовою та ціновою діяльністю. При цьому досить важливо є правильно організувати збутову та цінову діяльність, оскільки вони є важливими елементами, від яких залежить ефективність діяльності підприємства.

Ключові слова: конкуренція, конкурентоспроможність, маркетинг, иінова діяльність, збутова діяльність.
\end{abstract}

\section{SALES AND PRICE ACTIVITY IN MANAGEMENT OF ENTERPRISE COMPETITIVENESS}

\section{Yuliia Kaliuzhna; Tetyana Borovyk; Viktoriia Danylenko}

\section{Poltava State Agrarian Academy, Poltava, Ukraine}

Summary. In modern conditions, the complexity of political, economic and social factors influences the efficiency of enterprise's operation. The price setting is a very important stage for enterprise competitiveness, because the purpose of its operation is to obtain maximum profit. In addition, the company must not only produce, but also sell its products with a condition for making a profit, and this becomes possible only with the right choice of pricing and sales policies.

While research practice, it was discovered in the article, that in management of the enterprise competitiveness an important role is played by marketing elements, which are sales and pricing policies. They occupy one of the key positions in the enterprise activity, as they are the final stage of its operation, and more precisely, of final product sales to the consumers. Consequently, it was investigated that in management of enterprise competitiveness there is a relationship between sales and price activities. At the same time, it is very important to properly organize sales and pricing activities, as they are important elements on which the enterprise effectiveness depends.

Key words: competition, competitiveness, marketing, price activity, sales activity. 
Постановка проблеми. В умовах сьогодення конкуренція змушує суб'єктів підприємницької діяльності не зупинятися на досягнутому, а постійно самовдосконалюватися, знижувати витрати на виробництво, покращувати якість продукції. Провідна роль у забезпеченні конкурентоспроможності підприємства належить управлінню, яке передбачає цілеспрямовану, упорядковану й злагоджену діяльність, яка спрямована на підтримання об'єкта управління його розвитку та функціонування для ефективнішого досягнення поставленої цілі.

Для ефективного функціонування та 3 метою забезпечення підприємства необхідною інформацією про ринок і власні можливості розробляють комплексний маркетинг. Він охоплює такі напрями: товарний, комунікаційний, збутовий, ціновий та кадровий.

На сьогодні збутова та цінова діяльність займають одну з ключових позицій в основі управління конкурентоспроможністю діяльності підприємства, адже вони $є$ заключним етапом реалізації споживачам кінцевого продукту.

Аналіз останніх досліджень і публікацій. Проблеми, пов'язані з формуванням ефективної системи управління виробничо-збутовою діяльністю аграрних підприємств, $€$ об'єктом досліджень учених у галузі економіки, маркетингу, підприємництва та ін. Над теоретичними і практичними аспектами маркетингових підходів у виробничо-збутовій політиці десятиліттями працювало багато зарубіжних та вітчизняних науковців, зокрема: Л. Балабанова, Ю. Бєлова, О. Слець, І. Зеленчук, К. Курбатков, Р. Фатхутдінов, В. Холод.

Р. Фатхутдінов зауважує, що конкурентоспроможність підприємства - це здатність досягати конкурентних переваг над іншими підприємствами на конкретному ринку [10, с. 45].

К.С. Курбатков зазначає, що «конкурентоспроможність $є$ однією 3 найважливіших категорій сучасної ринкової економіки, яка означає суперництво між організаціями, які мають за мету забезпечити кращі можливості збуту продукції та задоволення різних потреб споживача» [7, с. 38].

Теоретичним і практичним питанням розвитку збутової та цінової діяльності присвячені праці І. Балабанова, 3. Бандури, Л. Вейкрута, П. Вінкельманна, Н. Гудзенко, С. Шпилика.

Німецький дослідник П. Вінкельманн зазначає, що при маркетинговому управлінні збутом виконується чотири основні функції-планування, організація, мотивація і контроль. Вони охоплюють усі види управлінської діяльності [3, с. 126]. С. Шпилик виділяє в якості управління підприємством такі функцій: планування, організування, мотивування, контролювання та регулювання [11, с. 88].

Із точки зору Н.М. Гудзенко, організація збуту залежить від потенціалу підприємства та обраної ним збутової політики [4, с. 264]. 3.Л. Бандура, Л.С. Вейкрута зазначають, що управління збутовою діяльністю є складним, багатогранним процесом і вимагає постійного аналізу й удосконалювання, зумовлює поступове збільшення обсягів реалізації вітчизняних виробників [2, с. 22].

Ціни і цінова політика - найважливіші елементи маркетингу підприємства. Від них залежить досягнення комерційного успіху, а цінова політика здійснює довготривалий і вирішальний вплив на всю діяльність підприємства [1, с. 147]. Крім того, автори зазначають, що «з точки зору маркетингу ціна товару - це оцінка його споживчої вартості з позиції того, хто виробляє або обмінює товар».

Отже, до інструментів маркетингу відносять рекламу, збут, обслуговування покупця, політику цін, вивчення потреб і попиту. А основними елементами в управлінні конкурентоспроможністю підприємства є збут та ціна.

Мета статті. У сучасних умовах в управлінні конкурентоспроможності 
підприємства досить важливою є правильно організована збутова та цінова діяльність, оскільки їх рівень є важливим показником для будь-якого підприємства. Від них залежать результати виробничо-збутової діяльності, такі, як прибуток і дохід підприємства.

Проте варто зазначити, що, незважаючи на значну кількість наукових праць та досягнень у цій галузі, виникає проблема в розумінні взаємозв'язку ціни, збуту та управління конкурентоспроможністю підприємства, оскільки в умовах загострення конкурентної боротьби необхідно правильно визначати систему їх взаємодії, що й зумовлює необхідність проведення даного дослідження.

Постановка завдання. Аналіз і систематизація теоретико-методологічних підходів до збутової та цінової діяльності на підприємстві, а також визначення їх ролі в управління конкурентоспроможності підприємства.

Виклад основного матеріалу. Розглядаючи поняття «конкурентоспроможність підприємства», варто зазначити, що саме конкурентоспроможність характеризує можливість та ефективність адаптації підприємства до сучасних умов ринку. Сучасний стан ринкового середовища характеризується постійною зміною зовнішніх факторів, мінливою спроможністю купівельного попиту, наявністю великої кількості підприємств різних форм власності. Отже, щоб вижити, підприємствам необхідно реагувати на всі зміни, що відбуваються в їх конкурентному середовищі з метою збереження своїх позицій на ринку й забезпечення конкурентних переваг. Тобто, підприємству потрібно правильно оцінювати ситуації на ринку 3 тим, щоб вибрати ефективні засоби конкуренції, які б відповідали нинішнім ринковим умовам України та діяльності підприємства.

Одна 3 неодмінних умов конкурентоспроможності для підприємств $\epsilon$ їх поінформованість про ринок, наявних конкурентів, нововведення інших характеристик, що дозволить їм мати повне уявлення про зовнішнє середовище та тенденції його розвитку.

Управління конкурентоспроможністю підприємства, як і будь-який механізм управління загалом, передбачає наявність суб'єктів та об’єктів діяльності. Якщо на макроекономічному рівні суб'єктом управління конкурентоспроможністю $є$ державні органи, а об'єктом - уся економічна інфраструктура країни, то на мікрорівні суб'єктом управління виступає підприємство, а об'єктом - весь його складовий потенціал [6, с. 144].

Отже, механізм управління конкурентоспроможністю підприємства являє собою сукупність засобів і методів, за допомогою яких здійснюється вплив на весь наявний зовнішній та внутрішній потенціали підприємства, з урахуванням тенденцій ринкової ситуації з метою отримання в майбутньому бажаного рівня конкурентоспроможності.

Для забезпечення конкурентоспроможності необхідне комплексне функціонування всіх елементів механізму. Схему механізму управління конкурентоспроможністю підприємства можна представити таким чином (рис. 1).

Отже, з рисунка 1 бачимо, що існує нерозривний зв'язок між використанням маркетингу і конкурентоспроможністю підприємства: чим повніше й ефективніше використовує підприємство в своїй діяльності принципи і методи маркетингу, тим більше стають його шанси на функціонування в сучасних умовах та утримання довготермінових конкурентних переваг.

Серед чинників, які суттєво впливають на рівень конкурентних переваг сільськогосподарських підприємств, доцільно виокремити маркетингові чинники, а саме: дослідження кон'юнктури ринку; оптимальна цінова політика; логістичне забезпечення, політика просування та стимулювання збуту. Маркетинг охоплює значну кількість проблем, що мають відношення не лише до збуту виробленої продукції, але й 
безпосередньо впливає на процес іiї виробництва.

Слід відзначити, що теоретично всі елементи маркетингу вже давно розкриті, зокрема й для умов аграрного виробництва. Але, наразі, велика кількість аграрних підприємств не використовує у своїй організаційній структурі службу маркетингу. Більше того, хотілося б відзначити, що опитування деяких керівників вітчизняних аграрних підприємств доводить, що переважна більшість 3 них не передбачає впровадження маркетингової діяльності і взагалі не розуміють сутності та особливостей даного виду діяльності. Тому не вважають за необхідне використовувати можливості підвищення рівня конкурентоспроможності своїх підприємств та своєї продукції на основі застосування комплексу маркетингу.

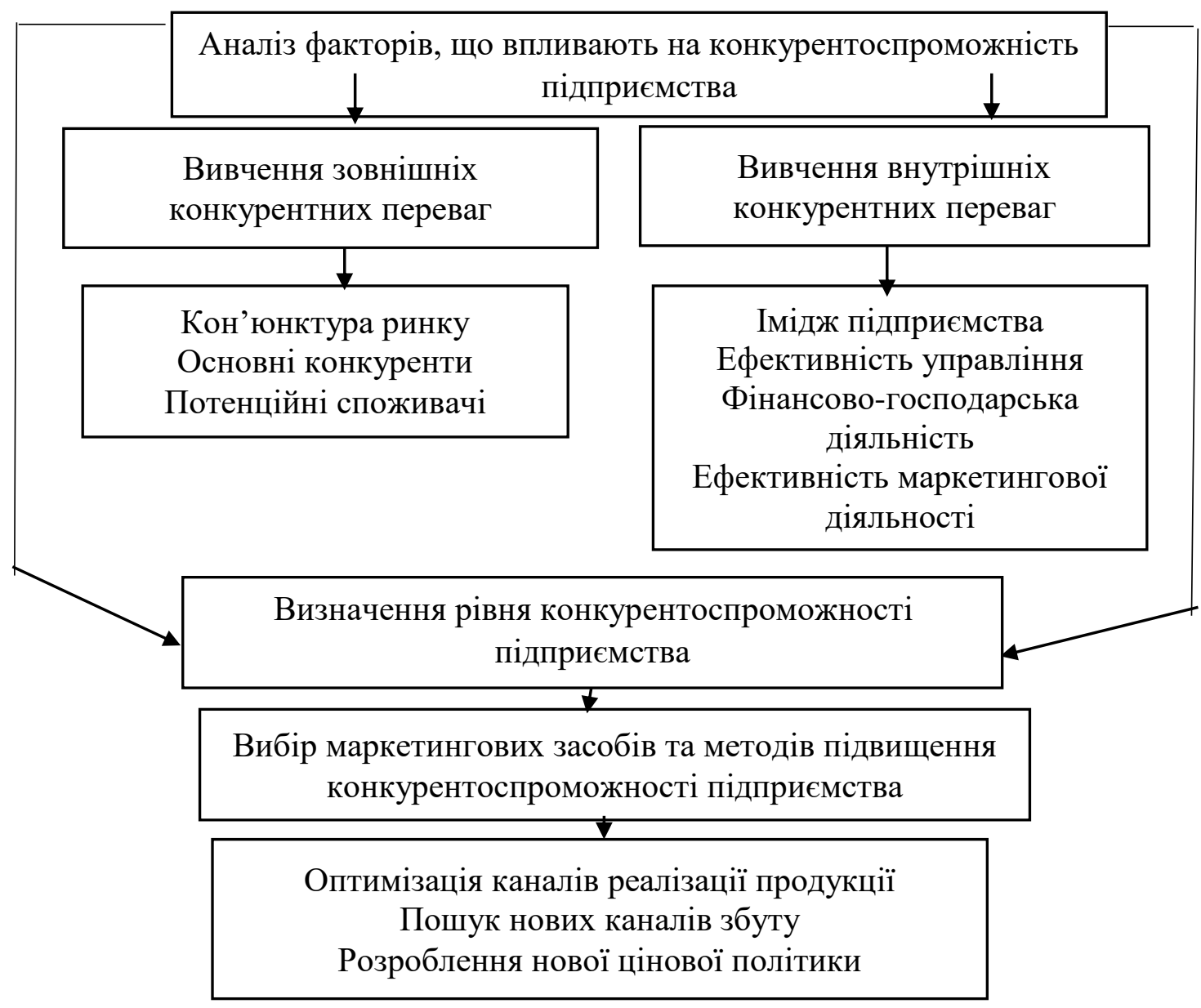

Рисунок 1. Механізм управління конкурентоспроможністю підприємства (розроблено на основі джерел $[5,6]$ )

Figure 1. The mechanism of enterprise competitiveness management (developed on the basis of sources [5, 6])

На нашу думку, саме через пристосування основних інструментів комплексу маркетингу з теоретичної основи до практичних дій аграрна сфера зможе підвищити рівень конкурентоспроможності підприємств та й взагалі покращити результати їх виробничо-господарської діяльності на довготривалу перспективу.

Маркетинг орієнтує збутову діяльність на виявлення та задоволення потреб споживачів для досягнення поставлених цілей, відбувається планування асортименту 
сільськогосподарської продукції. Етап планування збутової діяльності завжди пов'язаний зі здійсненням аналізу внутрішнього і зовнішнього середовищ, збиранням та опрацюванням інформації, на основі якої приймаються управлінські рішення, розробляється стратегія збутової діяльності.

Основними елементами збутової політики в умовах ринкової конкуренції $є$ такі:

- транспортування продукції - фізичне переміщення від виробника до споживача;

- доопрацювання продукції - підбір, сортування, збирання готового виробу тощо, що підвищує ступінь доступності й готовності продукції до споживання;

- зберігання продукції - організація створення й підтримка необхідних ії запасів;

- контакти зі споживачами - дії з фізичного передавання товару, оформлення замовлень, організації платіжно-розрахункових операцій, юридичного оформлення передавання прав власності на товар, інформування споживача про товар і фірму, а також збирання інформації про ринок [8, с. 26].

Саме тому першочерговим завданням підприємств $є$ створення ефективного управління збутовою та ціновою діяльністю. Вона повинна включати вирішення тих теоретико-методичних завдань, пов'язаних 3 економічним оцінюванням діяльності, проведенням системних досліджень кон'юнктури ринку, створенням відділу маркетингу та логістики, плануванням і формуванням аналітичного й інформаційного забезпечення.

У сучасних умовах на формування ціни впливає комплекс політичних, економічних та соціальних чинників. Для підприємства $є$ досить важливим етапом установлення ціни, адже метою його функціонування є отримання максимального прибутку. Також важливо, щоб ціна відповідала якості товару. Обрана підприємством цінова політика впливає на ефективність його роботи на ринку. Кожному підприємству необхідно не лише виробити, а й збути свій товар з умовою отримання прибутку. Це стає можливим лише за правильного вибору цінової політики та стратегії ціноутворення.

Ціна - один з найважливіших елементів маркетингової діяльності підприємства на ринку. Вона $є$ тією складовою маркетингового комплексу, яка визначає конкурентоспроможності продукції. В ринкових умовах ціни на сільськогосподарську продукцію формуються під впливом попиту й пропозиції і виступають у якості важливого чинника розвитку сільськогосподарського виробництва.

За ціновою політикою також існують стратегії створення різних конкурентних переваг підприємств. До першої стратегії відносять цінове лідерство, при якому центр уваги підприємств при виробництві продукції - це витрати.

Диференціація є наступною стратегією створення цінової конкурентної переваги.

Третьою ціновою стратегією, яку підприємства можуть використовувати для формування своїх конкурентних переваг, слід вважати концентрацію уваги на інтереси конкретних або окремих споживачів. Реалізуючи стратегію концентрованого формування при виборі та користуванні конкурентними перевагами підприємств, можливо використовувати одночасно як ціновими залученнями споживачів, так i диференціацією [9, с. 58].

За допомогою виробничих функцій можна визначити різні параметри для високоефективного ведення виробництва. Дослідимо за допомогою виробничої регресії вплив середніх цін реалізованої продукції зернових та зернобобових культур на обсяг реалізації зернових та зернобобових культур за останні десять років.

Для побудови цієї залежності припустимо, що між фактором - середні ціни 
реалізованої продукції зернових, зернобобових культур та показником - обсягом реалізації зернових та зернобобових культур існує лінійна залежність, яка виражається формулою

$$
Y p=a_{1} X+a_{0} .
$$

Для розрахунку залежності використовуємо Microsoft Excel, вбудовані функції Microsoft Excel та надбудову «Пакет аналізу».

В результаті опрацювання даних отримано регресійну модель залежності обсягу реалізації зернових та зернобобових культур від середніх цін реалізованої продукції зернових та зернобобових культур

$$
Y p=5,21 X+45853,37
$$

Коефіцієнт а 1 вказує на ступінь впливу фактора, в даному випадку середньої ціни реалізованої продукції зернових та зернобобових культур, на результативний показник, тобто обсяг реалізації зернових та зернобобових культур. Тому зі зміною цього фактора на одиницю змінюється результативний показник. Вільний член рівняння лінійної регресії економічного змісту не має.

Отже, отримані коефіцієнти $\mathrm{a}_{1}=5,21$ та $\mathrm{a}_{0}=45853,37$ вказують, що при зростанні середніх цін реалізованої продукції зернових та зернобобових культур на 1 грн. обсяг реалізації зернових та зернобобових культур збільшиться на 5,21 тис. т.

Наступний етап дослідження - розрахунок коефіцієнта кореляції. Отримані залежності оцінюють за рівнем показників тісноти зв'язку. Якщо їх абсолютна величина менша 0,3 - зв'язок слабкий; коли вона в межах 0,3 - 0,7 - середній, якщо 0,7 - тісний. Коли абсолютна величина дорівнює 1 , то це вказує на практичнофункціональний зв'язок.

Коефіцієнт кореляції $\mathrm{r}=0,62$, що свідчить про середній зв'язок між середніми цінами реалізованої продукції зернових та зернобобових культур і обсягом реалізації зернових, зернобобових культур та прямий вплив цього фактора на результативний показник.

Значення коефіцієнта еластичності під час зростання середніх цін реалізованої продукції зернових та зернобобових культур збільшується від 0,08\% до 0,30\%. Коефіцієнт еластичності показує, на скільки відсотків зміниться показник, якщо фактор зміниться на $1 \%$.

Також проведено дослідження обсягу реалізації зернових та зернобобових культур за допомогою лінійного тренду. В результаті опрацювання даних за допомогою лінійної трендової моделі отримано регресійну модель

$$
Y p=2184,90 X+43642,33 .
$$

Загальний коефіцієнт детермінації $\mathrm{R}^{2}=0,53$ свідчить про прямий середній зв'язок фактора й показника та якість моделі (рис. 2). 


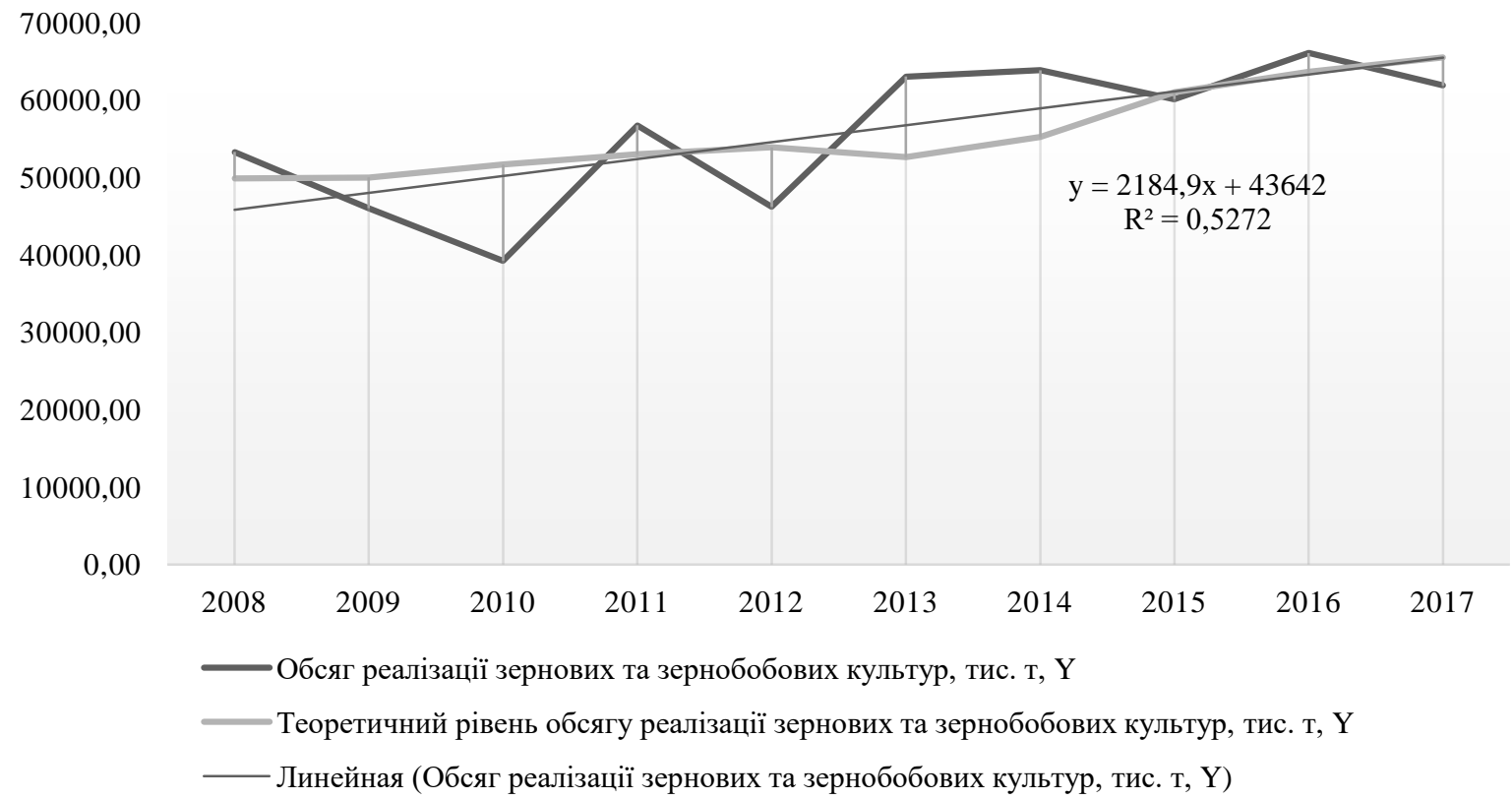

Рисунок. 2. Фактичний та теоретичний рівні обсягу реалізації зернових, зернобобових культур сільськогосподарськими підприємствами та лінійний тренд

Figure 2. Actual and theoretical levels of sales of grain and legume crops by agricultural enterprises and linear trend

Для побудови виробничої залежності припустимо, що між фактором - середні ціни реалізованої продукції сільськогосподарських тварин (у живій масі) та показником - обсягом реалізації м'яса (у забійній масі) існує лінійна залежність, яка виражається формулою

$$
Y p=a_{1} X+a_{0}
$$

У результаті опрацювання даних отримано регресійну модель залежності обсягу реалізації м'яса (у забійній масі) від середніх цін реалізованої продукції сільськогосподарських тварин (у живій масі)

$$
Y p=0,02 X+1944,33 \text {. }
$$

Коефіцієнт а 1 вказує на ступінь впливу фактора, в даному випадку, середньої ціни реалізованої продукції сільськогосподарських тварин (у живій масі) на результативний показник, тобто обсяг реалізації м'яса (у забійній масі).

Отже, отримані коефіцієнти $\mathrm{a}_{1}=0,02$ та $\mathrm{a}_{0}=1944,33$ вказують, що при зростанні середніх цін реалізованої продукції сільськогосподарських тварин (у живій масі) на 1 грн. обсяг реалізації м’яса (у забійній масі) збільшиться на 0,02 тис. т.

Наступний етап дослідження - розрахунок коефіцієнта кореляції. Отримані залежності оцінюють за рівнем показників тісноти зв'язку. Коефіцієнт кореляції $\mathrm{r}=0,61$, що свідчить про середній зв'язок між середніми цінами реалізованої продукції сільськогосподарських тварин (у живій масі) й обсягом реалізації м'яса (у забійній масі) та прямий вплив цього фактора на результативний показник.

Значення коефіцієнта еластичності під час зростання середніх цін реалізованої 
продукції сільськогосподарських тварин (у живій масі) збільшується від 0,08\% до 0,20\%. Коефіцієнт еластичності показує, на скільки відсотків зміниться показник, якщо фактор зміниться на $1 \%$.

Також проведено дослідження обсягу реалізації м'яса (у забійній масі) за допомогою лінійного тренду. В результаті опрацювання даних за допомогою лінійної трендової моделі отримано регресійну модель

$$
Y p=52,72 X+1904,93 \text {. }
$$

Загальний коефіцієнт детермінації $\mathrm{R}^{2}=0,78$ свідчить про прямий тісний зв'язок фактора й показника та якість моделі (рис. 3).

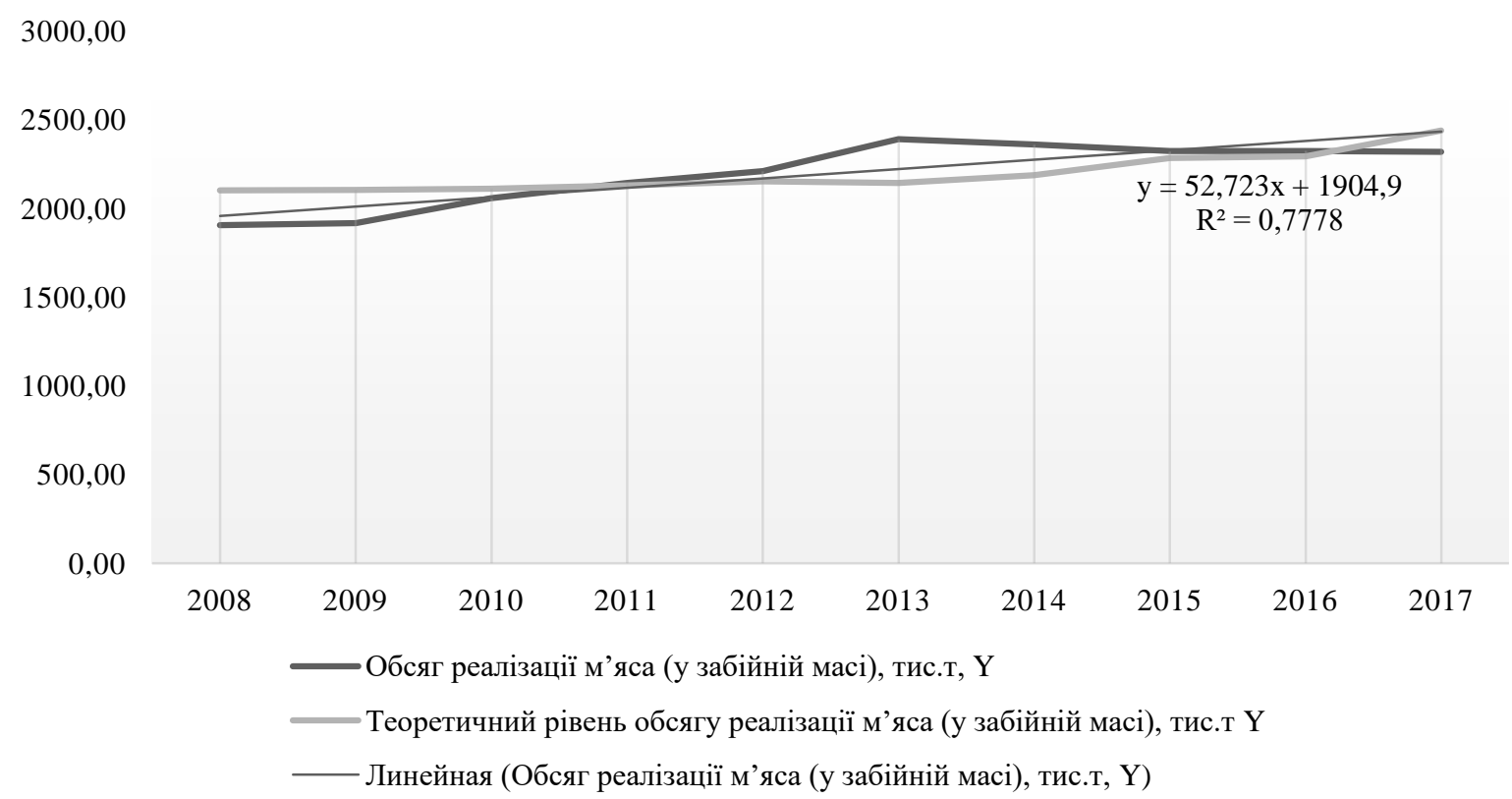

Рисунок. 3. Фактичний та теоретичний рівні обсягу реалізації м'яса (у забійній масі) сільськогосподарськими підприємствами та лінійний тренд

Figure 3.The actual and theoretical levels of sales of meat (in slaughter mass) by agricultural enterprises and the linear trend

Для побудови виробничої залежності припустимо, що між фактором - середні ціни реалізованої продукції молока та показником - обсягом реалізації молока існує лінійна залежність, яка виражається формулою $Y p=a_{1} X+a_{0}$.

У результаті опрацювання даних отримано регресійну модель залежності обсягу реалізації молока від середніх цін реалізованої продукції молока

$$
Y p=-0,29 X+12159,15
$$

Отже, отримані коефіцієнти $\mathrm{a}_{1}=-0,29$ та $\mathrm{a}_{0}=12159,15$ вказують, що при зростанні середніх цін реалізованої продукції молока на 1 грн. обсяг реалізації цієї продукції зменшиться на 0,29 тис. т.

3 метою визначення якості розрахованої моделі необхідно провести аналіз F-критерію Фішера. $\mathrm{y}$ даному випадку $\mathrm{F}_{\text {розр }}=47,93$ та $\mathrm{F}_{\text {таб }}=5,32$, оскільки $\mathrm{F}_{\text {розр }}(47,93)>\mathrm{F}_{\text {таб }}(5,32)$, то багатофакторну лінійну економетричну модель із надійністю 
$\mathrm{P}=0,95$ можна вважати адекватною експериментальним даним і на підставі прийнятої моделі можна проводити економічний аналіз обсягу реалізації молока.

Наступний етап дослідження - розрахунок коефіцієнта кореляції. Коефіцієнт кореляції $\mathrm{r}=0,93$, що свідчить про тісний зв'язок між середніми цінами реалізованої продукції молока й обсягом реалізації молока та прямий вплив цього фактора на результативний показник.

Оскільки $\mathrm{t}_{\text {роз }}>\mathrm{t}_{\text {табл }}\left(\mathrm{t}_{0,95,8}=2,31\right.$ та $\left.\mathrm{t}_{\mathrm{pos}}=4,24\right)$, з надійністю $\mathrm{P}=0,95$ можна зробити висновок про значущість коефіцієнта кореляції.

Значення коефіцієнта еластичності під час зростання середніх цін реалізованої продукції молока коливається від $0,05 \%$ до 0,21\%. Коефіцієнт еластичності показує на скільки відсотків зміниться показник, якщо фактор зміниться на 1\%.

Також проведено дослідження обсягу реалізації молока за допомогою лінійного тренду. В результаті опрацювання даних за допомогою лінійної трендової моделі отримано регресійну модель

$$
Y p=-150,54 X+11926,09
$$

Загальний коефіцієнт детермінації $\mathrm{R}^{2}=0,79$ говорить про прямий тісний зв'язок фактора й показника та якість моделі (рис. 4).

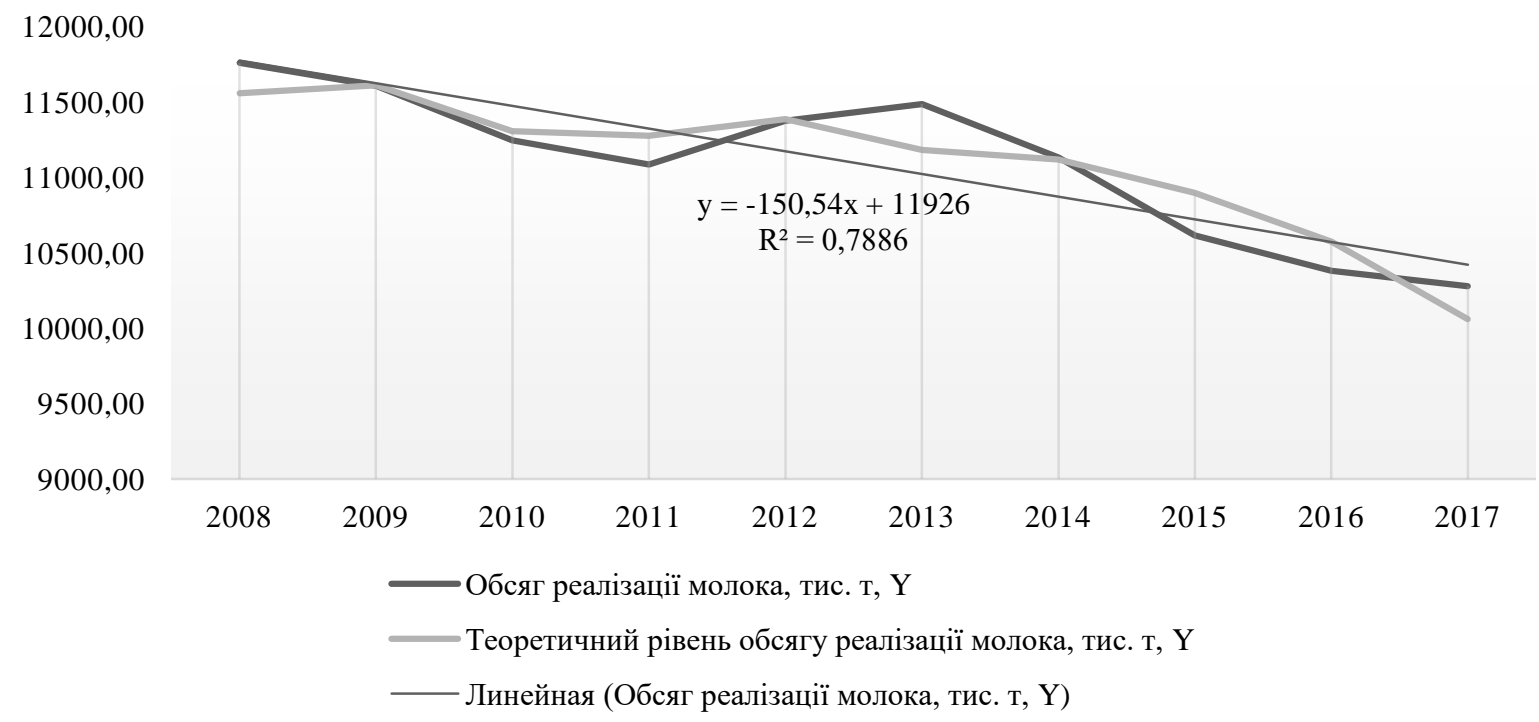

Рисунок 4. Фактичний та теоретичний рівні обсягу реалізації молока сільськогосподарськими підприємствами та лінійний тренд

Figure 4. The actual and theoretical levels of milk sales by agricultural enterprises and the linear trend

Саме безперервний процес взаємоузгодження взаємодії елементів маркетингу дозволяє підприємствам активно розвиватися, конкуруючи на ринку в умовах вітчизняного ринку.

Висновки. Дослідження зв'язку між елементами маркетингу в управлінні конкурентоспроможністю свідчить, що хоча між даними параметрами існує пряма залежність, але на даний час підприємства зосереджуються переважно на рекламуванні своєї продукції. При зміні ситуації на ринку, появі конкурентів 3 досвідом роботи, позиції даних підприємств дестабілізуються. Тому виникає потреба в розширенні практики просування продукції через посилення конкурентоспроможності підприємства 
на основі підвищення факторів використання збутової та цінової діяльності, що призведе до більшої прибутковості й дохідності.

Тому на сьогодні маркетингове забезпечення конкурентоспроможності передбачає використання інструментів маркетингу та способів їх поєднання з метою посилення конкурентних позицій підприємства та його продукції. Конкуренція, як економічна категорія, сприяє вирішенню таких завдань: упровадження нової техніки й технології, розвиток інформаційної системи, пошук оптимальних критеріїв виробництва, зниження цін на продукцію, поліпшення якості продукції, зниження собівартості продукції, удосконалення комплексу маркетингу на підприємстві. А оцінювання конкурентоспроможності аграрного підприємства і потребує ретельного аналізу технологічних, виробничих, фінансових та збутових можливостей підприємства, які будуть спрямовані на забезпечення його конкурентоспроможних позицій.

Conclusions. The study of the relationship between the elements of marketing in the management of competitiveness indicates that although there is a direct relationship between these parameters, but the time provided by enterprises focuses mainly on the promotion of their products. When the situation on the market changes, the emergence of competitors with experience, the position of these enterprises is destabilizing. Therefore, there is a need to expand the practice of promoting products through increased competitiveness of the enterprise by increasing the factors of use of sales and pricing activities, which will lead to greater efficiency and profitability.

Therefore, today, marketing support for competitiveness involves the use of marketing tools and how to combine them to strengthen the competitive position of the company and its products. Competition as an economic category contributes to solving the following tasks: the introduction of new equipment and technology, the development of an information system, the search for optimal criteria for production, lower prices for products, improving product quality, reducing the cost of production, improving the marketing complex at the enterprise. And the evaluation of the competitiveness of the agrarian enterprise just requires a thorough analysis of the technological, production, financial and sales opportunities of the company, which will be aimed at ensuring its competitive positions.

\section{Список використаної літератури}

1. Балабанова Л. В., Холод В. В., Балабанова І. В. Маркетинг підприємства: навч. посіб. Київ.: Центр учбової літератури, 2012. 612 с.

2. Бандура 3. Л., Вейкрут Л. С. Маркетинговий аналіз збутової діяльності підприємства в умовах ринку. Вісник Львівської комерційної академії, 2011. Вип. 36. С. 22-26.

3. Винкельманн П. Маркетинг и сбыт. Основы ориентированного на рынок управления компанией: учеб. пособ. / пер. с нем. - Москва.: Изд. дом Гребенникова, 2006. 668 с.

4. Гудзенко Н. М. Роль обліку збуту для забезпечення контролю процесу реалізації. Науковий вісник Національного аграрного університету. 2002. Вип. 56. С. 263-265.

5. Єлець О. П., Бєлова Ю. Г. Методичні підходи до управління конкурентоспроможністю підприємства. Ефективна економіка. 2013. № 4. URL: http://www.economy. nayka.com.ua/?op= $1 \& z=1951$ (дата звернення: 30.01.2019).

6. Зеленчук І. Б. Механізм управління конкурентоспроможністю молокопереробних підприємств. Актуальні проблеми економіки. 2015. № 3 (165). С. 144-154.

7. Курбатков К. С. Маркетинг і організаційно-економічні умови розвитку збутової діяльності в ринкових умовах. Харків: Основи, 2000. 243 с.

8. Макаренко М. В. Підвищення конкурентоспроможності промислової продукції шляхом застосування ефективної маркетингової концепції збуту. Актуальні проблеми економіки. 2008. № 1. С. 26-34.

9. Мандич О. В. Стратегії підвищення конкурентоспроможності підприємств на основі поєднання окремих теорій. Warsaw, Poland. East European Scientific Journal. № 1 (17). 2017. Part 2. С. 55-60.

10. Фатхутдинов Р. А. Конкурентоспособность: экономика, стратегия, управление. Москва: ИНФРА-М, 2000. 312 c.

11. Шпилик С. Управління збутовою діяльністю підприємства. Галицький економічний вісник. 2012. № 4 (37). С. $88-95$. 


\title{
References:
}

1. Balabanova L.V., Kholod V.V., Balabanova I.V. (2012) Marketynh pidpryyemstva: navch. posib. [Marketing of the enterprise] Kyyiv.: Tsentr uchbovoyi literatury. (In Ukrainian).

2. Bandura Z.L., Veykrut L.S. (2011) Marketynhovyy analiz zbutovoyi diyalnosti pidpryyemstva v umovakh rynku. [Marketing analysis of sales activity of the enterprise in the market conditions] Visnyk Lvivskoyi komertsiynoyi akademiyi. Vol. 36., pp. 22-26.

3. Vinkel'mann P. (2006) Marketing i sbyt. Osnovy oriyentirovannogo na rynok upravleniya kompaniyey: ucheb. posob. [Marketing and sales. Fundamentals of market-oriented company management:] Moskva.: Izd. dom Grebennikova. (In Russian).

4. Hudzenko N.M. (2002) Rol obliku zbutu dlya zabezpechennya kontrolyu protsesu realizatsiyi. [The role of sales accounting to ensure control over the implementation process] Naukovyy visnyk Natsionalnoho ahrarnoho universytetu. Vol. 56., pp. 263-265.

5. Yelets O.P., Byelova YU. H. (2013) Metodychni pidkhody do upravlinnya konkurentospromozhnistyu pidpryyemstva [Methodical approaches to enterprise competitiveness management] Efektyvna ekonomika. No. 4. Available at: http://www.economy.nayka.com.ua/?op=1\&z=1951

6. Zelenchuk I.B. (2015) Mekhanizm upravlinnya konkurentospromozhnistyu molokopererobnykh pidpryyemstv. [Mechanism of competitiveness of milk processing enterprises] Aktualni problemy ekonomiky. Vol. 165., No. 3., pp. 144-154.

7. Kurbatkov K.YE. (2000) Marketynh i orhanizatsiyno-ekonomichni umovy rozvytku zbutovoyi diyalnosti $\mathrm{v}$ rynkovykh umovakh. [Marketing and organizational and economic conditions of marketing activities in market conditions] Kharkiv: Osnovy. (In Ukrainian).

8. Makarenko M.V. (2008) Pidvyshchennya konkurentospromozhnosti promyslovoyi produktsiyi shlyakhom zastosuvannya efektyvnoyi marketynhovoyi kontseptsiyi zbutu. [Increasing the competitiveness of industrial products by applying an effective marketing marketing concept] Aktual \ni problemy ekonomiky. No. 1., pp. 26-34.

9. Mandych O.V. (2017) Stratehiyi pidvyshchennya konkurentospromozhnosti pidpryyemstv na osnovi poyednannya okremykh teoriy [Strategies for increasing the competitiveness of enterprises based on a combination of separate theories] East European Scientific Journal vol. 17., no. 1., pp. 55-60.

10. Fatkhutdinov R.A. (2000) Konkurentosposobnost: ekonomika, strategiya, upravleniye. [Competitiveness: economy, strategy, management] Moskva: INFRA-M. (In Russian).

11. Shpylyk S. (2012) Upravlinnya zbutovoyu diyalnistyu pidpryyemstva. [Management of sales activities of the enterprise] Halytskyy ekonomichnyy visnyk. Vol. 37., No. 4., pp. 88-95.

Отримано 23.02.2019

\section{УДК 658.1:334.716}

\section{ІНФОРМАЦИЙНЕ ЗАБЕЗПЕЧЕННЯ УПРАВЛІННЯ РОЗВИТКОМ ПРОМИСЛОВОГО ПІДПРИЕМСТВА В УМОВАХ ІНФОРМАЦІЙНОЇ ЕКОНОМІКИ}

\author{
Олексій Квілінський
}

\author{
Європейський університет, Київ, Украӥна
}

\begin{abstract}
Резюме. Опрацюювання інформаційних масивів, необхідних промисловим підприємствам для прийняття обгрунтованих рішень щзодо управління розвитком в умовах інформаційної економіки, неможлива без використання комплексу спеціалізованих програмних $і$ технічних засобів, а також інструкиій та регламентів щзоо збору, зберігання, опрацүювання та передавання інформації. Цей комплекс засобів складає інформачійне забезпечення при управлінні розвитком промислового підприємства в умовах інформаційної економіки. В статті розроблено інформаційне забезпечення управління розвитком промислового підприємства в умовах інформаційної економіки, в основу якого покладено принципи побудови регламентної, технічної та програмної складової забезпечення й упровадження якого на промислових підприємствах надає можливість підвищити оперативність й
\end{abstract}

